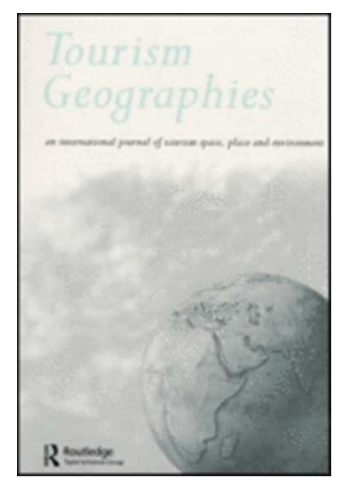

\title{
Leveraging Physical and Digital Liminoidal Spaces: the Case of the \#EATCambridge Festival
}

\begin{tabular}{|r|l|}
\hline Journal: & Tourism Geographies \\
\hline Manuscript ID & Draft \\
\hline Manuscript Type: & Research Article \\
\hline Keywords: & $\begin{array}{l}\text { Liminoid Spaces, Social Media, Creative Resistance, Food Festivals, } \\
\text { Cambridge, Event Leveraging }\end{array}$ \\
\hline
\end{tabular}

\section{SCHOLARONE ${ }^{\text {'N }}$}

Manuscripts 


\title{
Leveraging Physical and Digital Liminoidal Spaces: the Case of the \#EATCambridge Festival
}

\begin{abstract}
This paper conceptualises the way physical and digital spaces associated with festivals are being harnessed to create new spaces of consumption. It focuses on the ways local food businesses leverage opportunities in the tourist-historic city of Cambridge. Data from a survey of 28 food producers (in 2014) followed by 35 in-depth interviews at the EAT Cambridge food festival (in 2015) are used to explain how local producers overcome the challenges of physical peripherality and why they use social media to help support them challenges restrictive political and economic structures. We present a new conceptual framework which suggests the development of place through food festivals in heritage cities can be understood by pulling together the concepts of 'event leveraging', 'liminoid spaces' (physical and digital) and modes of 'creative resistance' which helps the survival of small producers against inner city gentrification and economically-enforced peripherality.
\end{abstract}

\section{Key words:}

Liminoid Spaces, Social Media, Creative Resistance, Food Festivals, Cambridge, Event Leveraging.

\section{Introduction}

Typified as one of Northern Europe's most popular touristic-historic cities, Cambridge has approximately 123,900 permanent residents (ONS, 2011), and attracts approximately 4 
million visitors per year (Tourism South East, 2010) making it the ninth most popular UK city for international tourism (Visit Britain, 2016). Given its size, Cambridge punches above its weight with a visitor to resident ratio of $32: 1$ and an annual rate of growth of $2.9 \%$ Gross Value Added according to the Centre for Economics and Business Research (cited in The Telegraph, 2016) and is the sixth fastest growing city in the UK by population (Centre for Cities, 2016). As of 2015, tourism and the wider visitor economy contribute $£ 19600 \mathrm{~m}$ [domestic], and $£ 22072 \mathrm{~m}$ [overseas] (Tourism South East, 2016) to the South East region, bolstered by world-leading industries from technology, science, education, right through to retail and having close geographical proximity to London. It is however important to note that such growth does not always benefit all stakeholders. The city's central commercial zones have been subject to intense corporate creep since the start of the 21 st century. Gentrification effects, aided by year or year growth, have served to corporatise central spaces predominantly focused on both retail and hospitality high street offer. According to latest figures, house prices in Cambridge are rising rapidly, with the Centre for Cities (2016, p.52) stating that 'nine out of 62 cities were less affordable than the British average, with Oxford, London and Cambridge being the least affordable cities'. With respect to commercial lettings the National Audit Office (2017) identifies the Cambridgeshire region as having some of the highest business rate growth in the UK with between $4.6 \%-9.6 \%+$ increases. Explored and evidenced throughout the paper, we illustrate the challenges this poses for local, smaller stakeholders, namely the 'pricing out' of smaller traders and producers, forcing independent food and drink businesses to occupy peripherally located premises.

Through a study of the EAT Cambridge food and drink festival (\#EAT) which started in 2013, this paper explores the role of social media, connected across the life of festivals in providing platforms that bridge the spatial and economic conflict between 'core' vs. 
'periphery'. We argue that festivals provide a powerful collaborative vehicle for small producers, where one all-encompassing social media identity is built around a physical event ensures alternative food producers are stronger than if they use social media marketing separately and independently. Building on the premise that physical and digital networks help grow and solidify existing networks across an 'in-between' space between core and periphery, we examine this relationship in the context of this tourist-historic city (Ashworth and Tunbridge, 2000). Given that social media and the internet are relatively inexpensive compared with other advertising media (Standing and Vasudavan, 2000), we explore the \#EAT brand to ascertain whether it offers a fairer playing field for smaller producers and companies, thus addressing any deficit that individuals may have in terms of their own 'digital capital'. Consequently, we explore how such media is being utilised to disrupt traditional approaches to place promotion (Kaplan and Haenlein, 2010), and establishing a series a tactical and longer-term strategic leveragable event-induced and related opportunities (e.g. Chalip, 2004).

The research questions (RQ) for this study were:

RQ1: In what ways do food and drink festivals provide leveragable benefits for participating local and small businesses?

RQ2: How do food and drink festivals act as a vehicle of promotion and enhance marketing communications efforts between producers and consumers - physically and digitally? 
RQ3: Why are food and drink festivals and their associated social media activities an important medium for showcasing the 'local' offer?

RQ4: Using EAT Cambridge as a case study, how do food and drink festivals act as key drivers that contribute toward place development?

\section{Literature Review \\ Event leverage: festivals as leveragable opportunities}

Events and festivals provide leveragable opportunities for a range of stakeholders and differing levels of urban geographies (Chalip and Leyns, 2002). These include the village, town, city, region, nation as a wider macro construct, right through to the individuals and small producers within and across targeted localities for which such economic intervention takes place. The act of cultivating and maximising such opportunity is referred to as 'event leveraging' (see Chalip, 2004; Weed, 2008). Events have the potential to provide local business with economic benefits borne by the event visitor economy if the festival and participating traders appropriately leverage them (e.g. O'Brien and Chalip, 2008, Misener et al., 2015). Smaller, grassroots festivals are particularly ripe for leverage as they occur annually and are usually bottom-up and locally-focused (e.g. Taks et al., 2013). Event managers seek to promote such leveragable opportunities as they can enhance tangible and intangible socio-economic benefits for participants, local host, and regional communities and promote a strong economic, and sustainable tourism outcome (e.g. Schulenkorf and Schlenker, 2017). It has been argued that smaller, locally focused events can be better leveraged to achieve such sustainable outcomes (Ziakas and Boukas, 2016), particularly as 
such interventions encourage and retain greater expenditure inside the destination and avoids external and economic leakage.

To conceptualise the dynamics of leveraging Chalip (2004) developed the 'Event Leverage Model' (ELM) (sometimes referred to as the 'Economic Leverage Model' e.g. Weed, 2008). As illustrated by Figure 1 below, the model is split into four columns to be read from left to right (i.e. Leverageable resource $\rightarrow$ Means). ELM illustrates how such interventions encompass a range of immediate and longer-term opportunities and outcomes that characterise and constitute the 'event'. For example, in the context of the Olympics, Duignan (2017) and Pappalepore and Duignan (2016) note these range from the Cultural Olympiad four years prior, Opening and Closing Ceremonies, right through to the longer-term cultural projects and events hosted in the proceeding years. To extend the application of this model, this paper will outline how a food festival can foster a range immediate and longer-term opportunities (leverageable resources) - that require targeted strategies and tactics to realise positive tourism and economic developmental benefits (e.g. Chalip, 2002). The food and drink industry is a pertinent sector to analyse as such commodities are an essential element of human survival, but in turn, a competitive industry that provides visitors with the freedom to choose what and how they consume (e.g. Taks et al., 2013).

Insert: [Figure 1 - Chalip's (2004) Event Leverage Model]

Solberg and Preuss (2007, p. 214) claim the 'pre-event' phase tends to be 'overlooked in discussions of long-term impacts because the focus is on legacy of an event, which by definition occurs post-event period'. Analysis of leverage within smaller scale events is underexplored, specifically the 'immediate' tactics within ELM that have been a neglected 
focus of this particular. To access 'immediate' bounties borne by the event visitor economy, specifically to 'optimise total trade and revenue' hosts must: (1) 'entice visitor spend', (2) 'lengthen visitors' stays', (3) 'retain event expenditures, and (4) enhance business relationships' (Chalip, 2004). Chalip notes the festival must seek to avoid 'economic leakage' of event expenditure, which can in turn secure local benefits by retaining spend and sourcing products (and even labour) - locally. The ability for the event to enhance 'business relationships' forms the final vital component of achieving 'immediate' leverage providing access to local and visiting business people (physically and digitally) for those 'associated with event participation, or whose business provide supplies or services to the event' (Chalip, 2004: 237). Throughout the application of ELM we argue in the context of Cambridge and \#EAT the pertinent issue is 'why' small traders chose to engage in event leveraging.

\section{Festival tourism: liminal and liminoid spaces and places}

Place-specific festivals are said to support and leverage a community's sense of place (Cresswell, 2004), transform spaces and identities, and offer opportunities for tourism revenue generation (Getz, 2005). However despite the growing body of event literature (Getz and Page, 2016), the call to embrace different dimensions of events tourism remain (Kim, Boo and Kim, 2013). As the literature has evolved, increasing emphasis has been placed on the complexities and motivations behind what has been simply defined as themed, public celebrations' (Getz, 2007, p.1). One dimension is the adoption of the concept of liminality to describe how festivals might be considered a form of 'social limbo' (Turner et al., 1983). It is perhaps unsurprising that liminality has become a popular concept in tourism literature, given its transformative effects for (re)structuring power and spatial dimensions (Thomassen, 2016). 
Picard and Robinson (2006) argue festivals are liminal zones in that the transformation of social space gives way to non-traditional behaviours. The idea of festivals championing subversion and the triumph of non-dominant values in less rigid, prescriptive spaces is certainly well established (Caudwell and Rinehart, 2014). Consequently, liminality in an event context is used to describe a temporary setting which encourages individuals to experience freedom from the mundane existence of everyday life (Shields, 1990), offering transitional dwelling spaces (Shortt, 2015). Festivals sit outside of the everyday structures of life and in turn are useful lenses to view and explore how liminality often refers to the subversion of hierarchy. Where 'festival spaces are arguably locations for both the liminal and the carnivalesque' (Pielichaty, 2015, p.236) must be examined within a matrix comprised of local identity, uniqueness, authenticity and liminality (Ma and Lew, 2012).

However, Pielichaty (2015) argues that liminality is traditionally associated with sacred inbetween spaces and the transitional, so suggests the concept of 'liminoidal' may provide a better lens for critical exploration of the transformation of everyday as it is less ritualistic. This builds on Turner (1992, p.57) who suggests that liminoid phenomena often lie outside the central economic and political processes as they are 'plural, fragmentary and experimental' and 'often subversive, representing radical critiques of the central structures and proposing utopian models'. Although studies have suggested festivals are complex spaces where structures are blurred (Weichselbaumer, 2012), they are perhaps not the temporary release from normative structures traditionally presented. Rather than presenting festivals as inversions of the everyday, the more economic and political urgencies of sustainability, politics and impact have become important, with more social control than might be imagined (Pielichaty, 2015). If this apparent politicisation of the festival space is to 
be fully explored, we need to move beyond research which prioritises the attendees and event goers, and also examine how local businesses are using such liminoidal opportunities. Perhaps rather than focus on the resistance and social protest undertaken by event goers so often described (Aching, 2010), we need to explore how local people and businesses are using them as platforms for social and economic change, challenge and leverage, both from a physical perspective but also increasingly demonstrating awareness of emergent digital 'liminoid' festival spaces.

\section{Social media in tourism: from the 'what' and 'how', to the 'why'}

Social media are said to offer platforms for 'resistance' and 'e-democracy' (Peters, Chen, Kaplan, Ognibeni, and Pauwels, 2013), redefining how businesses communicate across their channels of distribution and with their customers (Rapp, Skinner, Grewal, and Hughes, 2013). It is what Pechrová, Lohr, and Havlíček (2015) regard as a form of communication which enables niche markets to be served, and to emerge. Given the growth of internet users (e.g. The Economist, (2016) states $91.6 \%$ of the UK population regularly using the internet) and the rapid growth of social media adopters, it is little surprise the tourism literature seems to be struggling to keep pace with what it is providing and offering in terms of holistic consumer value and alternative spaces of tourism consumption (Leung, Law, Van Hoof, and Buhalis, 2013).

It is notable that Zeng and Gerritsen (2014) found studies of social media use in tourism were in their infancy, and argued for more studies on community engagement, marketing strategies, and differentiated destination management. It is increasingly apparent that the available literature on social media and tourism remains overly developmental and just 
moving from the 'what' question to the 'how' question' (Minazzi, 2015). It is only recently that the academic community has begun to theorise its role in challenging traditional knowledge and approaches to tourism marketing and consumer-engagement (Hudson and Thal, 2013). Tourism studies have to date fallen short on exploring 'how', and for the most part ignored the 'why' and questioned the reasons behind its use and adoption. Social media disrupts the rules of communication with customers, tending to highlight that brands need to be active on social media, but not explaining why (Leung et al., 2013), and what this means for wider urban development and community sustainability of these particular stakeholders.

Tourism literature on social media has tended to be somewhat fragmented and focused on isolated issues rather exploring its holistic impact and value (Felix, Rauschnabel and Hinsch, 2016). One broader issue which needs attention is how social media fosters links and traceability, shortening the distance between the destination and users, thereby strengthening user involvement and engagement in the innovation process. Undoubtedly social media has a role in transforming tourism and wider business practices by changing its boundaries and knowledge distances (Afuah and Tucci, 2012; Bogers, Afuah, and Bastian 2010), but research has been limited on how this effort can bring economic sustainability by challenging the need for physical space, and in turn occupy spaces that were once the domain of those with large marketing budgets.

The concept of social media as creating new spaces of consumption requires further exploration, and indeed is yet to be explored in terms of positive transformation of place. Literature exploring the ways different marketing media open up opportunities for smaller food producers remains in its infancy (Holt, Rumble, Telg, and Lamm, 2015). One idea put forward by Anderson (2007) is the 'long tail' theory which seeks to explain the shift away 
from a small number of mainstream producers and products toward a huge number of niches 'in the tail', but producer activity is yet to maximise the new market environment afforded by new media. Pechrová et al.'s (2015) study of farmers illustrates this well as they discovered many owners/managers were either unaware of social media tools or lacked the competency to effectively use them. The wider concern that smaller producers may lack the strategic, marketing, and operational skills, capabilities, capital, resources and mindset to access entrepreneurial opportunity is noted by Chalip and Leyns (2002) and Pappalepore and Duignan (2016) in the context of cultural and sporting events. Sturiale and Scuderi (2013) also demonstrate that communication between producer (farmer) and customer is not always being advanced on the three key levels of connection, conversation and construction (coproduction). Umbrella (food) organisations and associations, like that of EAT Cambridge, may well offer this competency and opportunity.

\section{Food festivals and the development of new networks and spaces}

In exploring the food movement in West Cork in Ireland, Broadway (2017) reemphasises how important a positive food image is in the selection of a destination by visitors, yet it is clear that local food offerings have taken time to feature at the centre of destination product offerings and marketing campaigns (Tikkanen, 2007). Although the body of work on foodmotivated travel has been expanding quickly (Everett, 2016; Getz, Robinson, Andersson, and Vujicic, 2014), much remains unknown about how tourists engage with alternative food providers and local festivals outside of the physical event, i.e. through pre and post event online marketing. Online promotion of food and related events remains patchy and overly simplistic (Kim et al., 2009). It is however clear from studies of food marketing that marketers and institutions no longer have ultimate control over the image of their destination 
or product (see Tresidder and Hirst, 2012). Rather, the power of user-generated content through websites are using the internet to (re)claim market territory from those with generous marketing budgets (Schegg and Fux, 2010).

Although most destination marketing materials now reference some form of culinary offer (Everett 2016), there is limited literature on the relationship between the adoption of social media marketing communications for food tourism events and their role in supporting local producers and future activities. Few studies have explored how social media linked to food and drink festivals have inspired the growth of food movements, and explored whether food tourism spaces and associated consumer leverage opportunities have become political (Starr 2010). As food movements grow, Watts et al. (2005) has argued that the nature of the alternative(s) is often unclear, fragmented and poorly communicated. Qazi and Selfa (2005: p.45) further queried whether small producers could effectively initiate alternative reconnections with consumers if they pursued more resistant approaches. Through better online marketing and communication, alternative production and products with an environmental consciousness may be better integrated with each other to create new places. Cultivating aspects of networking, synergies between the local event and business relationship opportunities has been noted as playing a part in long-term economic success of businesses and locations (O’Brien, 2006; Richards, 2015).

\section{Methodology}

An inductive exploratory, and mixed method approach was employed over two years to explore experiences of traders participating in the annual EAT Cambridge Food and Drink Festival [www.eat-cambridge.co.uk]. Primary data generation was undertaken in 2014 with a 
questionnaire-based survey (28 respondents), followed by 35 in-depth interviews in 2015 . The emailed survey asked 15 questions with a mix of open (qualitative) and closed (quantitative) questions covering their customer base, how they build business to business relationships; how they market their business; new marketing techniques, and innovation. The 2015 interviews used emergent themes from the previous survey to frame open questions to generate qualitative data on motivation, benefits of the festival, future growth, innovation, social media and marketing, challenges to their business, and Cambridge's food culture. Qualitative data generation is sensitive to the social context of the research was employed to unearth more meaningful elements in a multi-layered context (Mason, 2002) which made it a more appropriate approach in the discussion of such subjective topics. To minimise inconsistency, a pre-designed interview open question format was used in every interview. Excel and qualitative data analysis software (NVivo) were used to code data and identify emergent themes, with all four authors independently identifying emergent themes (researcher triangulation), before combining ideas through several data analysis meetings

The sample was purposive, incorporating the perspectives of the local producers involved. The survey used the festival's producers database, and the 2015 interviews were conducted at the event (some participants were the same, others were new and coded appropriately). The festival Director and Chief Executive of the Regional Destination Management Organisation were also interviewed. It was felt these two methods would provide a satisfactory level of 'data saturation' for the four research questions (Morse, 2000). Table 1 summarises the phases of data generation.

[Insert Table 1 here] 
Our sample represents $41 \%$ for 2014 , and $59 \%$ for 2015 of the overall population of small traders and local producers who took part, which subsequently helped to enhance the internal, and construct validity of the research. Table 2 summarises details of the 2014 survey respondents, and Table 3 summarises the 2015 interview respondents. All were coded to ensure anonymity and to aid data analysis.

[Insert Table 2 here]

[Insert Table 3 here]

\section{Findings and Discussion}

The literature review encouraged us to ask not only the 'what?', but more importantly the 'how' and the 'why' behind the relationship between social media and food festivals. In the context of digital and physical place development, we address these questions and illustrate how festivals manifest, not just as a single socio-economic intervention, but as a series of leveragable resources that serve to foster 'immediate' opportunities for participating producers and provide longer-term legacies for place development. In explaining and conceptualising the 'why', a simple framework of relationships between the digital and physical connected by the concept of 'creative resistance' is proposed and presented just before the conclusion. We start by outlining the Cambridge context before outlining what EAT Cambridge has to offer by presenting the festival as a series of 'leveragable resources'

\section{What? The Cambridge context and leveraging EAT Cambridge}


Local producers have, and continue to face systematic economic challenges associated with the gentrification of core city areas. Cambridge's economic and commercial growth over the past decade serves to explain why urban space emerges valorised. Both residential house prices and business rates continue to increase year on year and are set to rise again in-line with recent government policy to raise business rates by as much as $77 \%$ in $2017 / 18$ (Independent, 2017). Within densely occupied, centralised urban topologies like Cambridge, such effects have, and continue to, squeeze and 'price out' smaller, independent traders and producers. Spaces previously accessible are now largely inaccessible. Vulnerable producers of local artefacts operating within low-profit margins are unable to respond to the changing economic conditions. Several respondents alluded to their frustration at the corporatisation of Cambridge's high street, central spaces increasingly being dominated by 'cheap and easy fast-food chains' (AFD1'), and 'chain stores that dominate the high street' (AFD4).

'Find me a space! I'll open a deli! Find me a space that doesn't cost three thousand pounds [a month]...we could never afford somewhere in Cambridge city centre' (IC2).

Responses to questions about location suggests producers turn to the cheaper, less trodden path of peripheral and marginal urban districts - out of the way of lucrative centralities. Most respondents claimed they could not operate in the city so were being pushed out away from touristic central zones and associated benefits of its visitor economy. Central areas are largely dominated by corporate high street chains (Independent, 2010). Corporations are physically replacing independents - characteristic of neoliberal urban conditions and a mindset favouring global forms of cultural production (e.g. food, drink, and retail) over 'locally rooted' culture (e.g. Garcia, 2004). Cambridge is visibly illustrative of such corporatisation 
effects generally, given it is dubbed the UK's Number 1 'Clone Town' (New Economics Foundation, 2010). Interestingly, the idea of Cambridge as a 'Clone Town' typified views from respondents, claiming '[the] clone town is what Cambridge has become famous for' (BROL2). Conditions described across Cambridge illustrate the varying degrees of conflict between global and local demands whether from a cultural, economic, and physical-spatial perspective between, or as argued in this paper - the 'core' and the 'periphery'.

Evidence reveals that those businesses occupying a permanent central locality reflected a more positive, or at least ambivalent, attitude to the high city centre rents, indicating those businesses who 'have broken down barriers and made it into the centre' (Heidi). Tourism South East (2010) claims over 82\% of tourists only visit Cambridge for 3-9 hours, described by one respondent as the ' 8 hour tourist' (BROL 3) that typically stick to established central zones across the city centre. So, if located peripherally, it would be logical to assume small traders receive less, and limited opportunities to access tourism flows, presenting reasoning to why positive sentiments typify responses from centrally located respondents.

Findings support Chalip's (2004) model which suggested leveragable opportunities are realised through events. The festival has become a spatially dispersed series of 'leverageable resources' focused around 'discovering your local pantry' (EAT Cambridge, 2017). Interviewees were keen to point out it provides an opportunity to engage with central, peripheral, local, regional and national independent traders. As a consequence of its success, other similar cultural initiatives that have sprouted across the region (e.g. FoodPark, Night Markets (www.FoodPark.com) all under the banner of EAT Cambridge) and serve as a critical way to develop new spaces of consumption by connecting the visitor economy with 
more local, authentic cultural offerings, and attractions which support small traders. The next, arguably more pertinent question is 'how' this is happening.

\section{How? Creating and Maintaining Digital and Physical Liminoid Spaces}

EAT Cambridge provides a strategic array of physical events and reconfigured digital spaces, providing 'immediate opportunities' to secure leverageable benefits. With respect to the 'physical', these include festival event weekends in Cambridge, pop-ups (supper clubs, street food and night markets) and 'fringe events' across surrounding villages. These examples illustrate the wider, physicality of the festival across central and peripheral spaces, highlighting the festival's capacity to divert consumption beyond the core, whilst still drawing producers and consumers together centrally in the middle of the city to develop immediate leveragable short and longer-term opportunities (e.g. relationship development). These are both important components to what Chalip (2004) refers to as 'effective leverage'.

Physical, face-to-face interaction provided a significant opportunity to enhance brand awareness to directly engage with consumers. Traders were keen to stress that food festivals are 'just awareness, brand awareness. It is much cheaper, and to some extent more effective, to advertise by talking to customers at a stall in a festival than typical advertising [radio, TV]' (AFD1). Such 'conversational' approaches to 1-1 communication was referred to as 'inperson marketing' (AFD1); several respondents made it clear that this was the main reason why the alternative food businesses participate in food festivals. Traders remarked '...you actually get to speak to people, for food and drink, people need to actually see it and they need to try it' (C2) and 'it [EAT food festival] enables us to engage with exactly the right sort of people as well, who we want to talk to, people who are interested in our products' (DB3). 
'It's nice having the one-to-one customer interaction, that's definitely what we aim to get from road shows [food festivals], it definitely helps' (AFD1).

These findings partly address the concern expressed by Kim et al. (2010), who claimed that little research has been done to examine the relationships between perceived value and intention to revisit, and advocated analysis of small food festivals to properly explain visitors' behaviour and producer engagement. Across the two years of data generation, participants described the engagement they had with consumers at food festivals as an opportunity to 'educate consumers' (DB2), but the momentum had to be retained after the event in order to inspire forms of 'critical consumption' (e.g. Sassatelli and Davolio, 2010) between consumers and producers, and shift consumption preferences to focus on more locally orientate cultural offer.

'...our aim at the events we attended was to educate the public about our business and products, which in turn we hope will broaden our customer base, which should help grow and sustain our long term revenue and future' (D2).

The festival provided a physical place and 'in-person' catalyst to generate more sustainable relationships that were supported and nurtured by social media engagement. Physical components were complemented by a digital spaces created by online social mediums that facilitate customer-producer, customer-festival and producer-festival interactions. These include: i) official \#EATCambridge Twitter hashtag, ii) Facebook iii) Instagram iv) website and v) Director's (Heidi) blog: the 'MovingFoodie'. Digital platforms seem to form a major way of fostering and enhancing a festival-producer-consumer tripartite model of interactions. 
In $2014,93.1 \%$ of survey respondents agreed that the festival 'provided a platform to market their business' (27/29). 86\% either agreed (44.8\%) or strongly agreed (41.3\%) that \#EAT provided a much needed collaborative marketing opportunity, echoed by 25 respondents who agreed that social media 'provided an opportunity to expand their customer base' without physical presence in the 'core'. Additionally, it was clear that the festival played a fundamental role as the personal 'check in' to humanise the Twitter messages. This dual marketing strategy of physical presence followed by virtual communication as opposed to a one off event where messages are lost was welcomed by businesses.

Many felt their social media messages are often received but with little impact, content, or reassurance unless they are tied to a more 'central' event. Repeatedly, it was found that the omnipresent physical and digital platforms of \#EAT served to champion the 'local' - in terms of producers, products and cultural diversities on offer across Cambridge's region. As suggested later, a greater focus on slower forms of touristic experience, and the overarching critical contribution of EAT Cambridge and wider initiatives play in fostering a 'foodie movement' and resistance against aforementioned economic pressures and spatial disparities serves to underpin 'why' such interventions are important in characteristically neoliberal contexts like Cambridge city centre.

Many respondents saw the festival and the director (Heidi) as a gatekeeper - a major force in nurturing social networks which foster leveraging opportunities between producersconsumers. This emerged in light of the risks that gentrification can fragment qualitative and quantitative socio-economic dependencies communities rely-on (e.g. Raco and Tunney, 2010), thus reducing their competitiveness. Respondents explained how the festival, (literally and metaphorically) seems to bridge a spatial geographical-economic divide that physically 
and subjectively exists - exemplified across the local narratives underpinning these findings. This argument ripples throughout the empirical evidence of this paper, epitomised by a trader who claimed EAT Cambridge participation is all about...

'...gaining exposure to the Cambridge foodie crowd- breaking into a new cross section of local people that we haven't come into contact with much before' (...) '[the festival was a] great opportunity to get ourselves seen by a wide Cambridge (foodie) audience' (AFD 8).

Opportunities now became open, whereas without the festival, they would be closed or at best, more difficult to access. Producers regarded the festival as a promotional catalyst and opportunity to momentarily occupy the 'core', and then follow up with effective digital engagement. This tactical 'oscillation' between temporary physical leverage, and strategic leveraging and development of B2B and B2C relationships via digital platforms typified trader responses.

Twitter (and Facebook) emerged as playing a key role in local promotional strategies, with many relying on ‘@EatCambridge’ official Twitter account as a major conduit between the festival-producers-consumers tripartite relationship. Given their wide networks and 7,538 follows (as of $02 / 05 / 2017$ ) the impact of the festival team retweeting local traders tweets greatly extended local trader networks. Twitter was the most prominent with respondents who noted it 'helped me gain more respondents to my email marketing' (B2) and 'overall it is very beneficial in promoting our business, increasing awareness of our brand' (AFD6). \#EATCambridge was regarded as a vehicle which helped communicate messages they could not themselves, offering amplification, visibility and access to core markets. One trader 
remarked 'twitter is our main tool, 'When @Eat mentioned us or replied etc. we saw an increase in followers' interaction etc...' (BROL4). Most agreed that festivals helped shift consumer focus onto them, and not only provided an alternative, but helped them conduct business in a different way. For example, $50 \%$ of the 2014 respondents agreed it 'encouraged them to think about new marketing techniques', further reporting they were considering a deeper involvement with the festival by utilising fringe events linked with the festival. $62 \%$ of respondents felt that the festival 'made them think about the possibility of using fringe events in the future to attract custom in the longer-term'. In light of the social media opportunities, evidence indicated traders making a gradual migration toward integrating social media within marketing and communications strategies. Furthermore, some respondents claimed participation in events was driven by their need for interesting content on their Twitter feeds, Facebook posts, and Instagram uploads. On the other hand, many were using the events they attended and put on as 'content' (BROL3) for their tweets, posts and uploads.

\footnotetext{
'I think you really need to understand why people are using it [social media] (...) it [content on Twitter] has to be interesting content and have people that want to read it and be engaged by it... We want to do more events so that we have content [for social media] to talk about' (BROL3).
}

The 2014 survey found digital networks from the festival helped local producers develop their digital capital and open up new Twitter accounts. These were far more active by 2015 , with interviewees suggesting, 'we use Twitter, Instagram and Facebook and the success rate is that Twitter is more successful than Facebook and then Instagram is more of a visual showcase' (BROL 3), and 'so obviously I'm on twitter, so that's been very good' (B3). 
Almost every respondent stated that they were 'active on Twitter' (B3). Some have thousands of followers illustrating how 'we use Twitter a lot, the general [company] feed has over 2000 followers and our MD [Managing Director] has a 1000 so yeah it is a broad coverage there' (BROL 1). The harmonious balance between the physical and digital interactions between producers-consumers-festival was reiterated repeatedly by traders: 'meeting people at EAT was a really effective way to help us build social media followers and for us get connected with Cambridge foodies' (EA6). In light of this, it is of no surprise to find respondents claimed Twitter handle @EATCambridge and \#EATCambridge hashtag emerged vital to 'talk to people' (DB2). And that the 'Twittersphere' landscape was helping to build up 'brand recognition' (DB6). Furthermore, Twitter was seen as an efficient way to communicate to large, and wide pool of potential consumers as 'actively talking face-to-face [to customers] takes up quite a lot of time' (DB2). It was clear that digital engagement offered an opportunity to go beyond the local, region into the global spectrum of potential consumers who may decide to visit Cambridge as a visitor destination for its food and drink tourism scene.

'...everyday people pick up their phones and go on Twitter and Facebook, Instagram, so for people to see our product/brand on there [social media] is going to really get people to recognise it' (AFD1).

The 'follow the food' concept developed by Cook and Harrison (2007) is now an almost literal process via social mediums, like Twitter. Traders would use Twitter to showcase to their network of potential consumers a 'physical' trace indicating when they would pop up at other physical locations. In turn, potential consumers and their 'social networks' become coproducers of knowledge - sharing the geo-locations of the traders, thus using a form of 
online 'liminoid' space to provide digital clues to the physical locations of producers. Furthermore, the \#EATCambridge hashtag provides a suitable platform for valuable content generation to stimulate these conversations. What this may mean, is that following the trader within core spaces, and beyond into the periphery, continues to exemplify leveragable opportunities and helps marginalised producers 'transcend' the core in order to redistribute event related benefits (Ziakas, 2014). What we can see is that 'following' and 'tracing' supply chain components and physicality of trader presence may not just drive consumer value by giving immediate and ongoing reassurance to those visitors wanting to buy locally produced goods, but also provides traders with a virtual alternative to having a fixed trading space. Fixed, permanent, central spaces that have, by and large, become inaccessible for the average producer.

'...the general public started to recognise the brand when they are out and about. And recognise that the brand is local (DB2) (...) and 'the major benefit of the EAT was the coverage really, particularly the all-round coverage on Twitter. Every event has brochures and flyers so you can see what's going on. But Eat Cambridge on Twitter was incredibly good! I was always re-twitting, yeah!' (BROL 1).

The paper now shifts its attention to understanding 'why' festivals promote and produce such digital and physical space, and the wider, more conceptual reasons for their existence.

\section{Why? Creative resistance, foodie movement and recapturing space}

We have outlined the contextual challenges facing small producers and traders, and the idea that festivals provide a series of leverageable resources provide opportunities for the 
emergence of physical and digital liminoid spaces. Here we suggest festivals can manifest as a 'critical movement' and be conceptualised as forms of 'resistance'. EAT Cambridge can be seen as creating both physical and digital spaces, across a series of temporal phases, opening up 'lines of flight' for small traders to resist economic pressures and the tension between occupying 'core' vs. 'peripheral' commercial and geographical localities. We argue that this can be seen as both a logical outcome of such intervention, and one that emerges dominant in the empirical findings and small business narratives of this paper. Empirically driven, the data presented illustrates the power of festivals to disrupt traditional consumption practices and resist the spectre of the Clone Town effect. Social media, specifically, providing the platforms affording unique opportunities to prolong 'event leverage' - before, during, and after the physical aspects of the festival has disappeared and morphed into one of the many other food and drink fringe initiatives.

EAT Cambridge fosters what Deleuze and Guattari (1987) may theorise as modes of 'creative resistance'. Creative, locally rooted cultural products illustrate the plethora of leverageable resources available to resist, and in fact strengthen the emergence of an inclusive, alternative food movement. Direct, in person contact at physical events provide a powerful catalyst and foundation, for which social media can take over to provide a long term relationship builder. Evidence here illustrates the pertinence of oscillating between both physical and digital platforms and spaces across varying temporal frames. It has been argued that people and social media can never be detached from each other (Zhuo, Wellman and Yu, 2011), with Lim (2012, p.242) suggesting that 'social media may be viewed both as technology and space for expanding and sustaining the networks upon which social movements depend'. What became increasingly apparent was producers saw the adoption of social media as a way they could resist the centre, and challenge the dominant spatial orthodoxies in Cambridge. Social 
media offers a useful mechanism to transcend from the periphery to the 'core' as it provides a bridge - or - perhaps a 'third space'. Social media overcomes an in/out dualism, creating a space for transgressive discourse and self-affirmative resistance (Soja, 1996). The festival brand seems to have a role in the intersecting geometries of power, identity and meaning associated with the notion of liminality.

Respondents felt the festival was important in establishing an 'in-person' marketing approach, then social media built these relationships beyond the limited timeline of the physical festival. The festival's social media arm of \#EATCambridge was regarded by many respondents as a crucial education vehicle and a facilitator of what we could conceptualise as 'liminoid positionality', with a key role to play in the campaign to encourage consumers to buy from alternative food producers - engaging in modes of 'critical consumption'. Through building links across both core and peripheral locations with consumers, other businesses and festival gatekeepers, Twitter and Facebook were helping to traverse liminoidal spaces of the city, and simultaneously reduce the dependency on occupying core touristic urban centres. Festivals could therefore be seen as a way of 'democratising' non-traditional opportunities within challenging business environments, with both physical and digital liminoid spaces practically affording plurality of voice in an urban setting dominated by the narratives of corporate enterprise and global expressions of food and drink culture. As a result, festivals have the potential to support the wider redistribution of visitor economy benefits and improve the economic sustainability of peripherally located, and arguably more vulnerable smaller traders and producers (e.g. Ziakas, 2014), through stimulating greater small business positive, planned, unplanned, short and longer-term event 'legacies' (e.g. Preuss, 2015; Pappalepore and Duignan, 2016). 
The festival serves as a major role in stimulating food and drink tourism to the city and developing new sense of place. This was reflected on by several responded illustrating 'we [Cambridge] are becoming more of a foodie destination. People are more and more interested in food, and good quality food as well. There are more and more events, which prove that' (AFD1). It was remarked that the emerging 'foodie movement', could be moving beyond satisfying the demands of the local, regional Cambridgeshire population who have a somewhat protectionist attitude toward 'wanting to support their local traders' (CC2) - toward encouraging wider, national, European and international audiences. Evidence suggests this has, and continues to come to fruition, with the rise of new food and drink initiatives (FoodPark, Night Markets, themed nights and transformation of urban spaces to host ad-hoc and summer long festivals such as the Thirsty River Biergarten).

\begin{abstract}
'We're getting people who are choosing to come to Cambridge and they're doing their foodie research and go, 'Right! I want to eat in these establishments. They're cherry-picking us, and that's exciting!' (BROL3).
\end{abstract}

\begin{abstract}
Almost all respondents interviewed suggested Cambridge's food and drink scene had 'grown dramatically in the last 18 months' (IC2) characterised by the emergence of many new specialist food outlets and new event platforms. Many felt that they were part of a 'new movement', described as a 'revolution' (BROL 3). Director of EAT Cambridge felt that the 'foodie' movement is being driven by 'explosion in food blogging, cookbooks, food and drink on social media by people who treat food and drink experiences as a hobby and a topic to share' (Heidi). As identified earlier, although frustrated with the corporatisation of Cambridge's inner city, seen as a barrier to some, others were more positive and actually claimed that such challenging conditions had in fact promoted a form of local 'revolution'.
\end{abstract}


'I think it has [Cambridge foodie reputation] grown because there's been a frustration at this kind of clone town. Generally that frustration has led to a sort of revolution. I think it's been born out of independents wanting to act like we make a difference in our town' (BROL3).

Arguments presented so far illustrate that the 'new foodie movement' was seen as being financed by the relative economic prosperity of Cambridge's citizens, something that the responding businesses were acutely aware of stating that ' $I$ think the opportunity that Cambridge has is that it has a lot of relatively wealthy people to take advantage of' (B3). Consumers' high level of disposable income was said to be reflected in their 'willingness to be 'experimental' (B1), giving niche food producers, whose offering is premium products that are not found in high street chains - a market to sell. Intimations here, illustrate, the rather paradoxical nature of urban food movements as being inherently 'middle-class' as indicated previously by Sassatelli and Davoli (2010) and discussed more recently by Duignan and Wilbert (2017) in the context of Cambridge; an interesting qualifier with respect to the study's limited generalisability to different socio-economic contexts.

\footnotetext{
'Small vendors have recognised there is a financial confidence in Cambridge, therefore, the type of sort of foodie products that they want to sell - there is a market there for it and it is a constant market' (BROL3).
}

Alongside the growing festival scene, parallel emergence of more street traders and urban food trucks are seizing festival opportunities. What we found was a nascent, but strident resistance from businesses who currently occupy central locations within Cambridge to re- 
purpose, re-brand, and even re-name specific urban zones and streets within the city centre itself - unofficially referred to as 'Meat Street' down Cambridge's Bennett Street [official name]. Here, observational evidence illustrates an agglomeration of small, independently owned food and drink outlets attempting to resist and repel corporatisation. Interestingly, whilst accepting that higher rents are part of 'doing business', centrally located businesses of whom occupy permanent central trading space, made it very explicit that they were keen to break down barriers and sought to inspire other alternative food providers to rent a shop in the centre. Furthermore, they expressed the will to prove they could compete with the 'chain' businesses, to set an example to the rest of the foodie movement. There was a clear perception that being physically in the core was advantageous:

'...we are in a really good place, rather than let's say being out in the periphery, where it might have taken longer to prove our business and get recognition from customers and alike' (...) and I think for it to really take a foothold, you have to have permanent locations...so we can actually take on the kind of corporate giants that are in the game’ (BROL3).

Narratives of enterprising 'in' businesses were akin to that of an organised resistance group fighting back against the 'clone town that Cambridge has become famous for' (BROL3). They were aware of the need to educate consumers to stimulate modes of critical consumption, actively contesting and avoiding consumption within the city's large chain outlets, therefore contributing to an emerging and revised brand 'promoting Cambridge as a foodie destination' (AFD1). Again, the idea of 'creative resistance' here manifested as a hoped-for outcome; whereby alternative food providers promote an alternative (and resistant) artisan identity for the city. BROL1 and BROL3 talked about 'power in numbers' and about 
creating pockets of similar business that occupy certain areas of the city centre, labelling those zones as 'foodie' business areas.

\author{
'I think there's just power in numbers. So, the greater the scene gets, the more people \\ (customers) will use it and rely upon it, and support it. And that will attract more \\ people into either districts, the city centre' (BROL3).
}

\begin{abstract}
Although optimism radiated out of those occupying a central locality, businesses of whom occupy secondary locations outside official boundaries of the city centre (approximately two miles outer ring) were clearly much more defeatist generally, and specifically with respect to the chances of acquiring city centre trading space. 'Out' businesses talked less about fighting back against the chains and more about 'surviving' (IC2) and 'making a living' (DB2) having been locked out of the main city centre marked and remarked that 'I guess [I could] move out to the suburbs, or kind of the villages surrounding Cambridge, I actually think they're becoming more important' (B3), and 'we can afford in smaller areas, we've looked at like Saffron Walden and St Ives' (IC2). Several 'out' businesses realised the need to innovate and market themselves as a separate and alternative foodie 'destination' (B3) in of themselves. The leveragable value of the festival was raised as a vital part of this transition as it is assumed that 'people [consumers] travel to quality restaurants' (DB2).
\end{abstract}

\footnotetext{
'I think it's important, if you're really good and you have a good business and good quality produce, people will come to you and you know - you become a destination. You know, so you know they will come. And I think if you can't afford Cambridge, which most people can't, then it's going somewhere else and being good enough to survive there' (B3).
} 
Social media was perceived as a way to contest, traverse, and negotiate 'clone' spaces, allowing alternative producers to gain presence and reputation over their competition. Responses were indicative of what Girouz (1983) might have described as cultural struggles within sites of the everyday, and echoes Deleuze and Guattari (1987, p.33) who claim resistance is 'rhizomatic multiplicities of interactions, relations and acts of becoming', creating unexpected networks, connections and possibilities, and specifically notions of 'creative resistance'. The ability to achieve new opportunities was now possible through physical and digital linkages between producers-consumers as the festival was regarded as an umbrella brand that bridged respective stakeholder groups together in an intermixed physical and digital landscape.

Below, we present a relational model between concepts and context under investigation. Figure 2 illustrates several key features. The paper argues that festivals manifest as a series of short and longer-term leveragable resources, producing a plethora of digital and physical marketing and communications opportunities that connect the festival, producers and consumers together. In turn, this can be seen to afford producers to overcome and 'creatively resist' their peripheral locality generated by on-going valorisation of urban space and the Clone Town effects found within Cambridge, with generalisable features across a significant number of UK towns and cities (e.g. NEF, 2010). In turn, whilst the on-going gentrification and pricing out of smaller producers indicate a challenging condition of the corporatised, neoliberal city - it has fuelled and sparked an emergent wider 'foodie movement' that seeks to redistribute opportunities back to smaller producers who may have found themselves marginalised, and serve to open up and democratise urban space affording a plurality of 
narratives that disrupt the day to day naturalised assumptions associated with capitalistic modes of urban development and neoliberal doctrine.

Insert [Figure 2- Relationships between key concepts under investigation (developed by authors)].

\section{Conclusions}

This paper has suggested festivals can offer a form of open, fluid and 'democratised urban space' - egalitarian in nature and can be conceived of as 'liminoid spaces' which amplifies the voices and commercial opportunity for those of whom are often perceived as having a lower economic worth and contribution toward the vitality of the neoliberal-touristic city (Raco and Tunney, 2010). We have argued that the central tourist district in an historic city like Cambridge is not always open to alternative food providers given the high costs of rents and the dominance of space by 'clone' commercial interests and large multi-national food chains. Through a complex blend of physical components and amorphous digital presence across popular social mediums there is opportunity for a leveragable marketing and communication vehicle for alternative producers. \#EATCambridge acts as a food tourism amplifier, providing a temporary opportunity for alternative providers to occupy the 'core' physical space which is then built on and developed using social media. This paper has put forward the 'what' in terms of event leveraging, the 'how' in terms of the use of social media to develop physical and digital spaces, and the 'why' this is being done in regard to local producers engaging in forms of what we have theorised as 'creative resistance'. 
We have suggested that the concept of 'creative resistance' (Deleuze and Guattari, 1987) is useful in illustrating specific physical and digital tactics invoked to overcome peripheral locality and leverage event-induced benefits (building brand, presence, reputation, business/consumer engagement and relationships). Though the concepts of resistance and liminoid spaces, we have found that through co-creation with consumers, producer can resist the centre, create new destinations of their own, and challenge the dominant spatial orthodoxies in Cambridge. We find that social media offers a parallel digital and virtual space, providing producers with an opportunity to transcend the 'inbetweenness' of core and the peripheral; acting as a form of marketing bridge from their outside location to the 'core' of the city's economic activity. \#EATCambridge is an example of an organisation using social media to disrupt 'core' food and drink offerings in the form of subtle resistance against powerful and economic forces.

It is clear that social media linked to a high profile festival event offers alternative food providers in heritage cities with a powerful tool to create new spaces of consumption. Respondents felt social media facilitated their engagement in positive acts of resistance and provided consumers with a vehicle of critical consumption which helped them achieve greater local sustainability. Events and festivals provide, in this sense, an illustrative process of the democratisation of urban spaces. Collaborative social media approaches built from a central food event is proving vital for protecting local livelihoods, and the cultural identities that comprise the socio-economics of Cambridge's vibrant and diverse locale and regional food and drink scene places and spaces.

\section{References}


Aching, G. (2010). Carnival time versus modern social life: a false distinction: Social Identities. Journal for the Study of Race, Nation and Culture, 16 (4), 415425. doi.org/10.1108/IJEFM-02-2015-0009.

Anderson, C. (2007). The long tail: how endless choice is creating unlimited demand. London: Random House.

\begin{abstract}
Afuah, A., and Tucci, C. L. (2012). Crowdsourcing as a solution to distant search. Academy of Management Review, 37 (3), 355-375. doi:10.5465/amr.2010.0146.
\end{abstract}

Ashworth, G. J., and Tunbridge, J. E. (2000). The Tourist-historic City. London: Routledge.

Bogers, M., Afuah, A., and Bastian, B. (2010). Users as innovators: a review, critique, and future research directions. Journal of Management, 36 (4), 857-875. doi:10.1177/0149206309353944.

Broadway, M. J. (2017). 'Putting Place on a Plate' along the West Cork Food Trail. Tourism Geographies, 19 (3), 1-16. doi.org/10.1080/14616688.2016.1276615.

Caudwell, J. and Rinehart, R.E. (2014). Liminoidal spaces and the moving body: emotional turns. Emotion, Space and Society, 12 (1), 1-3. doi: 10.1016/j.emospa.2013.12.006.

Centre for Cities (2016). Cities Outlook 2016. Available at: http://www.centreforcities.org/wp-content/uploads/2016/01/Cities-Outlook-2016.pdf. [Accessed on 20 June 2017]. 
Chalip, L., and Leyns, A. (2002). Local Business Leveraging of a Sport Event: Managing an Event for Economic Benefit. Journal of Sport Management. 16 (1),.132-158. doi.org/10.1123/jsm.16.2.132.

Chalip, L. (2004). Beyond Impact: A General Model for Host Community Event Leverage. In: Ritchie, B., and Adair, D. (Eds). Sport tourism: Interrelationships, Impacts and Issues. Clevedon: Channel View.

Cook, I., and Harrison, M. (2007). Follow the thing "West Indian hot pepper sauce". Space and Culture, 10 (1), 40-63. doi: 10.1177/1206331206296384.

Cresswell, T. (2014). Place: an introduction. Oxford: Blackwell.

Deleuze, G. and Guattari F. (1987). A Thousand Plateaus. Minneapolis: University of Minnesota Press.

Duignan M.B (2017). Olympic territorialisation, shocks and event impacts: small businesses and London's 'Last Mile' spaces. Unpublished $\mathrm{PhD}$ Thesis, Anglia Ruskin University, UK.

Duignan, M.B., and Wilbert, C. (2017). Embedding Slow Tourism and the 'Slow Phases' Framework: the case of Cambridge, UK. In: Clancy, M. (Ed.). Slow Tourism, Food and Cities: Pace and the Search for the 'Good Life'. London: Routledge. 
Everett, S. (2016). Food and Drink Tourism: Principles and Practices. London: Sage.

Felix, R., Rauschnabel, P. A., and Hinsch, C. (2016). Elements of strategic social media marketing: A holistic framework. Journal of Business Research.

doi:http://dx.doi.org/10.1016/j.jbusres.2016.05.001.

Getz, D., and Page, S. J. (2016). Progress and prospects for event tourism research. Tourism Management, 52, 593-631. doi: 10.1016/j.tourman.2015.03.007.

Getz, D., Robinson, R., Andersson, T., and Vujicic, S. (2014). Foodies and food tourism. Oxford: Goodfellow Publishers.

Getz, D. (2005). Event management and event tourism (2nd ed.) New York: Cognizant.

Getz, D. (2007), Event Studies: Theory, Research and Policy for Planned Events. Oxford: Elsevier.

Giroux, H. A. (2003). Public pedagogy and the politics of resistance: Notes on a critical theory of educational struggle. Educational Philosophy and Theory, 35(1), 5-16. doi: $10.1111 / 1469-5812.00002$.

Holt, J., Rumble, J. N., Telg, R., and Lamm, A. (2015). The message or the channel: an experimental design of consumers' perceptions of a local food message and the media channels used to deliver the information. Journal of Applied Communications, 99(4), 6-20. Retrieved

from: 
http:/go.galegroup.com/ps/i.do?\&id=GALE $\mid$ A440822601\&v=2.1\&u=anglia_itw\&it=r\&p=A ONE\&sw=w\&authCount $=1$

Hudson, S., and Thal, K. (2013). The impact of social media on the consumer decision process: Implications for tourism marketing. Journal of Travel \& Tourism Marketing, 30 (12), 156-160. doi.org/10.1080/10548408.2013.751276

Independent (2010) Cambridge beats Exeter for title as UK's ultimate clone town. Available at: $\quad$ http://www.independent.co.uk/news/uk/this-britain/cambridge-beats-exeter-for-title-asuks-ultimate-clone-town-2079476.html. [Accessed on 4 July 2013].

Kaplan, A. M., and Haenlein, M. (2010). Users of the world, unite! The challenges and opportunities of Social Media. Business Horizons, 53 (1), 59-68. doi:10.1016/j.bushor.2009.09.003.

Kim, J., Boo, S. and Kim, Y. (2013). Patterns and trends in event tourism study topics over 30 years. International Journal of Event and Festival Management, 4(1), 66-83.

Kim, Y. H., Kim, M., Ruetzler, T., and Taylor, J. (2010). An examination of festival attendees' behaviour using SEM. International Journal of Event and Festival Management, 1(1), 86-95. doi.org/10.1108/17852951011029324.

Kim, Y. H., Yuan, J., Goh, B. K., and Antun, J. M. (2009). Web marketing in food tourism: A content analysis of web sites in West Texas. Journal of Culinary Science \& Technology, 7(1), 52-64. doi 10.1080/15428050902788352. 
Leung, D., Law, R., Van Hoof, H., and Buhalis, D. (2013). Social media in tourism and hospitality: A literature review. Journal of Travel \& Tourism Marketing, 30(1), 3-22.

Lim, M. (2012). Clicks, cabs, and coffee houses: Social media and oppositional movements in Egypt, 2004-2011. Journal of Communication, 62 (2), 231-248. doi:10.1111/j.14602466.2012.01628.x.

Ma, L. and Lew, A.A. (2012). Historical and geographical context in festival tourism development, Journal of Heritage Tourism, 7 (1), 13-31, doi10.1080/1743873X.2011.611595

Mason, J. (2002). (2nd edition) Qualitative Researching. London: Sage.

Minazzi, R. (2015). Social media marketing in tourism and hospitality. Switzerland: Springer.

Misener, L., Taks, M., Chalip, L., and Green, B.C. (2015), "The elusive 'trickle-down effect' of sport events: assumptions and missed opportunities", Managing Sport and Leisure 20(1), 135-156. doi/full/10.1080/23750472.2015.1010278.

Morse, J.M. (2000). Determining Sample Size. Qualitative Health Research 10 (1), 3-5. doi:10.1177/104973200129118183 
National Audit Office (2017). Planning for 100\% local retention of business rates. Available at: https://www.nao.org.uk/wp-content/uploads/2017/03/Planning-for-100-local-retention-oflocal-business-rates.pdf. [Accessed on 20 June 2017].

New Economics Foundation (2010). Re-imagining the High Street: Escape from Clone Town Britain. Available at: http://neweconomics.org/2010/09/reimagining-high-street. [Accessed on: 12 November 2014].

Office for National Statistics (2011) UK 2011 Census. Retrieved from http://www.ons.gov.uk/census/2011census.

Pantelidis, I. S. (2010). Electronic meal experience: A content analysis of online restaurant comments. Cornell Hospitality Quarterly, 51, 483-491. doi/10.1177/1938965510378574

Pappalepore, I. and Duignan, M.B. 2016. The London 2012 Cultural Programme: a Consideration of Olympic Impacts and Legacies for Small Creative Organisations in East London. Tourism Management. 54 (1), 344 - 355. doi.org/10.1016/j.tourman.2015.11.015.

Pechrová, M, Lohr, V. and Havlíček, Z. (2015). Social Media for Organic Products Promotion. Agris on-line Papers in Economics and Informatics 7 (1), 41-50.

Peters, K., Chen, Y., Kaplan, A. M., Ognibeni, B., and Pauwels, K. (2013). Social Media Metrics - A Framework and Guidelines for Managing. Journal of Interactive Marketing, 27(4) 281 - 298. doi:10.1016/j.intmar.2013.09.007. 
Picard, D., \& Robinson, M. (Eds.). (2006). Festivals, tourism and social change: Remaking worlds. Clevedon: Channel View.

Pielichaty, H. (2015) Festival space: gender, liminality and the carnivalesque. International Journal of Event and Festival Management, 6 (30), 235-250, doi: 10.1108/IJEFM-02-20150009

Pile, S., (1994). Masculinism, the use of dualistic epistemologies and third spaces. Antipode, 26 (3), 255-277. doi:10.1111/j.1467-8330.1994.tb00251.x.

Preuss, H., (2015). A framework for identifying the legacies of a mega sport event. Leisure Studies. 34 (6), 643-664. doi.org/10.1080/02614367.2014.994552.

Qazi, J.A., and Selfa, T.L. (2005). The politics of building alternative agro-food networks in the belly of agro-industry. Food, Culture and Society: An International Journal of Multidisciplinary Research, 8(1), 45-72.

Raco, M. and Tunney, E. (2010). Visibilities and Invisibilities in Urban Development: Small Business Communities and the London Olympics 2012. Urban Studies 47 (10), 20692091.doi 10.1177/0042098009357351.

Rapp, A., Skinner Beitelspacher, L., Grewal, D., Hughes, D. E. (2013). Understanding social media effects across seller, retailer, and consumer interactions. Journal of the Academy of Marketing Science. 41 (5), 547 - 566. doi 10.1007/s11747-013-0326-9. 
Sassatelli, R., and Davolio, F. (2010). Consumption, pleasure and politics: Slow Food and the politico-aesthetic problematization of food. Journal of Consumer Culture, 10 (2), 202-232. doi/abs/10.1177/1469540510364591.

Schegg, R., and Fux, M. (2010). A comparative analysis of content in traditional survey versus hotel review websites. Information and Communication Technologies in Tourism 2010, 429-440. doi 10.1007/978-3-211-99407-8_36.

Schulenkorf, N. and Schlenker, K. (2017), "Leveraging Sport Events to Maximize Community Benefits in Low-and Middle-Income Countries", Event Management, 21 (2), 217-231. doi:10.3727/152599517X14878772869766.

Shields, R. (1990). The 'system of pleasure': Liminality and the carnivalesque at Brighton. Theory, Culture and Society, 7 (1), pp. 39-72.

doi/abs/10.1177/026327690007001002.

Shortt, H. (2015) Liminality, space and the importance of 'transitory dwelling places' at work. Human Relations 68 (4), 633-658. doi/abs/10.1177/0018726714536938.

Solberg, HA., and Preuss, H. 2007. Major Sport Events and Long-Term Tourism Impacts. Journal of Sport Management 21 (1), 213-234. doi.org/10.1123/jsm.21.2.213.

Soja, E., (1996). Thirdspace: journeys to Los Angeles and other real-and-imagined places. Oxford: Blackwell. 
Starr, A. (2010). Local food: a social movement? Cultural Studies? Critical Methodologies, 10 (6), 479-490. Retrieved from: http://journals.sagepub.com/toc/csca/10/6.

Standing, C., and Vasudavan, T. (2000). The impact of Internet on travel industry in Australia. Tourism Recreation Research, $25 \quad$ (3), 45-54. doi $10.1080 / 02508281.2000 .11014924$.

Sturiale, L., and Scuderi, A. (2013). Evaluation of Social Media Actions for the Agrifood System. Procedia Technology. 8 (1), 200 - 208. doi:10.1016/j.protcy.2013.11.028.

Taks, M., Green, B.C., Chalip, L., Kesenne, S., and Martyn, S. (2013). Visitor composition and event-related spending. The International Journal of Event and Festival Management, 7(2), 132-147. doi: 10.1108/IJCTHR-04-2013-0020.

The Economist (2016) Pocket World in Figures: 2016. London: Profile Books.

The Telegraph (2016) Cambridge and Milton Keynes to lead UK growth in 2016. Available at: http://www.telegraph.co.uk/finance/economics/12065319/Cambridge-and-Milton-Keynesto-lead-UK-growth-in-2016.html [Accessed on 10 June 2017].

Thomassen, B. (2016). Liminality and the Modern: Living through the In-between. London: Routledge.

Tikkanen, I. (2007). Maslow's hierarchy and food tourism in Finland: five cases. British Food Journal, 109(9), 721-734. doi:10.1108/00070700710780698 
Tourism South East. (2010). Economic impact of tourism: Cambridge. City Results 2010. Eastleigh: TSE Research.

Tourism South East. (2016). Tourism Volume and Expenditure. Available at: http://www.tourismsoutheast.com/services-and-support/research/tourism-volume-andexpenditure.html. [Accessed on 19 June 2017].

Turner V (1992). Blazing the Trail: Way Marks in the Exploration of Symbols. Tucson, AZ: University of Arizona Press.

Turner, V., Harris, J.C. and Park, R.J. (1983). Liminal to liminoid, in play, flow, and ritual: an essay in comparative symbology. In Harris, J.C. and Park, R.J. (Eds), Play, Games and Sports in Cultural Contexts. Champaign, Illinois: Human Kinetics Publishers, pp. 123-164.

VisitBritain (2016). Inbound Town Data. Retrieved from: https://www.visitbritain.org/towndata. [Accessed on 19 June 2017].

Watts, D.C.H., Ilbery, B. and Maye, D. (2005): Making reconnections in agro-food geography: alternative systems of food provision. Progress in Human Geography 29 (1), 2240. doi/abs/10.1191/0309132505ph526oa.

Weed, M. (2008). Olympic Tourism. Oxford: Elsevier. 
Weichselbaumer, D. (2012). Sex, romance and the carnivalesque between female tourists and Caribbean men. Tourism Management 33 (5), 1220-1229.

doi.org/10.1016/j.tourman.2011.11.009

Zeng, B., and Gerritsen, R. (2014). What do we know about social media in tourism? A $\begin{array}{lllll}\text { review. } & \text { Tourism } & \text { Management } & \text { Perspectives, } & 10\end{array}$ doi.org/10.1016/j.tmp.2014.01.001.

Zhuo, X., Wellman, B., and Yu, J. (2015). Egypt: the first internet revolt? Boletim do Tempo Presente, (02). Retrieved from:

http://www.seer.ufs.br/index.php/tempopresente/article/viewFile/4224/3490.

Ziakas, V. (2014). For the Benefit of All? Developing a Critical Perspective in Mega-Event Leverage. Leisure Studies. 34 (1), 689-702. doi.org/10.1080/02614367.2014.986507.

Ziakas, V. and Boukas, N. (2016). The Emergence of 'Small-Scale' Sport Events in 'Small Island' Developing States: Towards Creating Sustainable Outcomes for Island Communities. Event Management, 20 (4), 537-563. doi; 10.3727/152599516X14745497664479. 


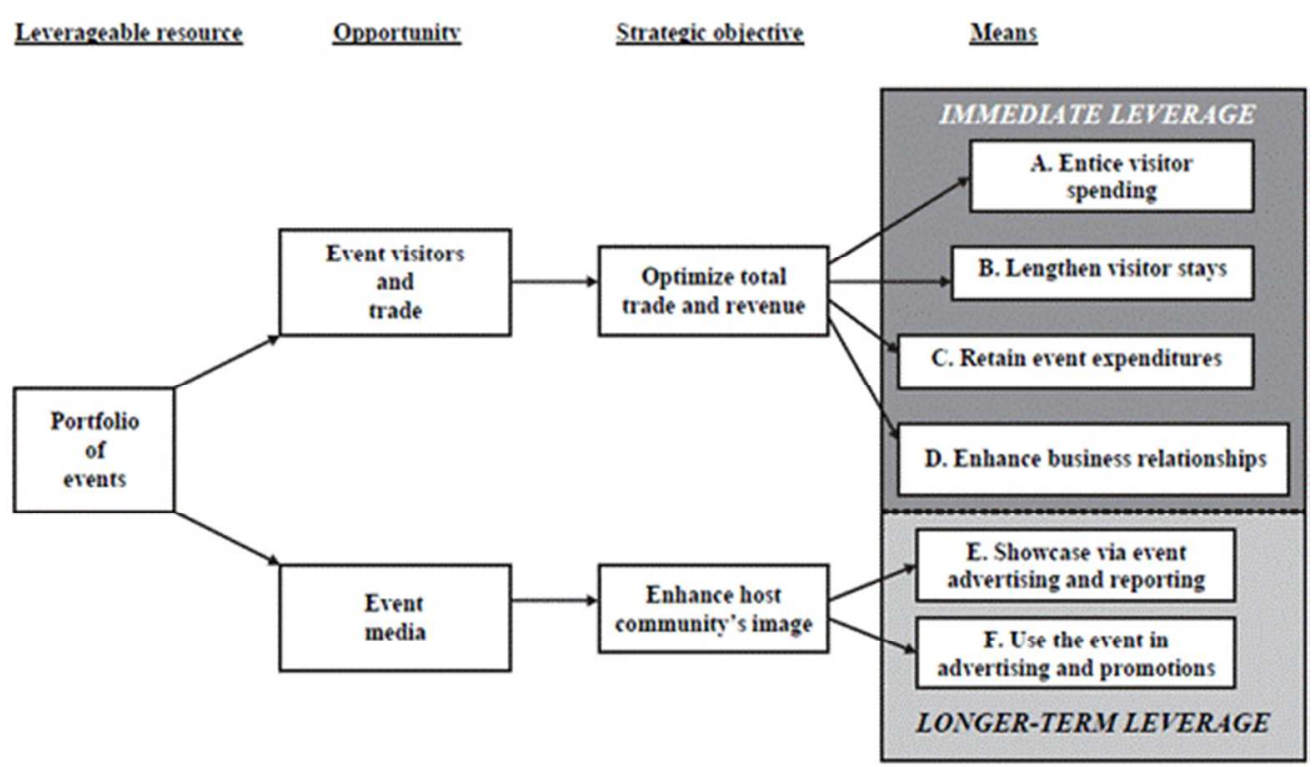

Figure 1. Chalip's (2004) Event Leverage Model

$159 \times 93 \mathrm{~mm}(96 \times 96 \mathrm{DPI})$ 


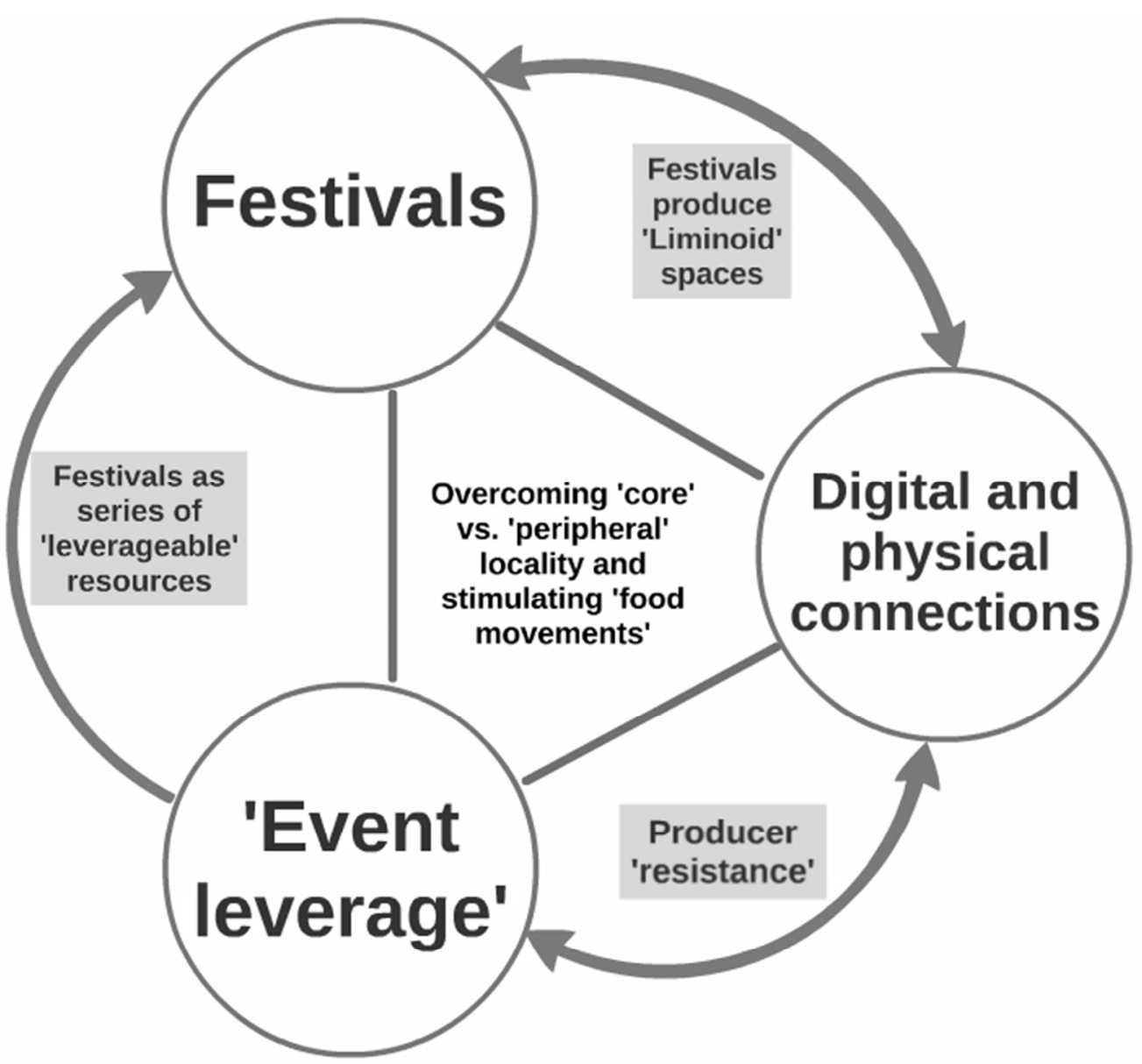

Figure 2 Relationships between key concepts under investigation (developed by authors) $185 \times 170 \mathrm{~mm}(96 \times 96 \mathrm{DPI})$ 
Table 1 - Summary of methods of data generation

\begin{tabular}{|l|l|l|}
\hline Method and timing & Process & Sample \\
\hline Phase 1: Survey & Emailed questionnaire to all local & 28 \\
producers registered for EAT Cambridge & \\
\hline Phase 2: Interviews & Face to face interviews by four authors at & 35 \\
(May 2015) & EAT Cambridge festival 2015 (33 traders & \\
& plus Director and Chief Executive) & \\
\hline
\end{tabular}


Table 2 Summary of survey respondents (2014)

\begin{tabular}{|c|c|}
\hline Survey respondents (2014) & $\begin{array}{l}\text { Code used for data analysis and } \\
\text { presentation }\end{array}$ \\
\hline Artisan 1 & AFD1 \\
\hline Artisan 2 & AFD2 \\
\hline Bakery 1 & B1 \\
\hline Bakery 2 & $\mathrm{~B} 2$ \\
\hline Bakery 3 & B3 \\
\hline Bakery 4 & B4 \\
\hline Bar/Restaurant 1 & BROL1 \\
\hline Bar/Restaurant 2 & BROL2 \\
\hline Chilli/Chutney 1 & $\mathrm{CC} 1$ \\
\hline Chilli/Chutney 2 & $\mathrm{CC} 2$ \\
\hline Chilli/Chutney 3 & $\mathrm{CC} 3$ \\
\hline Chocolatier 1 & $\mathrm{C} 1$ \\
\hline Coffee/Tea 1 & CT1 \\
\hline Coffee/Tea 2 & $\mathrm{CT} 2$ \\
\hline
\end{tabular}




\begin{tabular}{|c|c|}
\hline Deli 1 & D1 \\
\hline Deli 2 & D2 \\
\hline Deli 3 & D3 \\
\hline Deli 4 & D4 \\
\hline Distillery/Brewery 1 & DB1 \\
\hline Distillery/Brewery 2 & DB2 \\
\hline Accommodation 1 & EA1 \\
\hline Accommodation 2 & EA2 \\
\hline Accommodation 3 & EA3 \\
\hline Accommodation 4 & EA4 \\
\hline Accommodation 5 & EA5 \\
\hline Accommodation 6 & EA6 \\
\hline Ice Cream & IC \\
\hline Drinks 1 & NAD1 \\
\hline
\end{tabular}


Table 3 Summary of interviewees (2015)

\begin{tabular}{|c|c|}
\hline 2015 interview & $\begin{array}{l}\text { Code used for data analysis and } \\
\text { presentation }\end{array}$ \\
\hline Artisan 1 & AFD1 \\
\hline Artisan 2 & AFD2 \\
\hline Artisan 3 & AFD3 \\
\hline Artisan 4 & AFD4 \\
\hline Artisan 5 & AFD5 \\
\hline Artisan 6 & AFD6 \\
\hline Bakery 1 & B1 \\
\hline Bakery 2 & B2 \\
\hline Bakery 3 & B3 \\
\hline Bar/Restaurant 1 & BROL1 \\
\hline Bar/Restaurant 2 & BROL2 \\
\hline Bar/Restaurant 3 & BROL3 \\
\hline Bar/Restaurant 4 & BROL4 \\
\hline Chilli/Chutney 1 & $\mathrm{CC} 1$ \\
\hline
\end{tabular}




\begin{tabular}{|c|c|}
\hline Chilli/Chutney 2 & $\mathrm{CC} 2$ \\
\hline Chilli/Chutney 3 & $\mathrm{CC} 3$ \\
\hline Chilli/Chutney 4 & $\mathrm{CC} 4$ \\
\hline Chilli/Chutney 5 & $\mathrm{CC} 5$ \\
\hline Chocolatier 1 & $\mathrm{C} 1$ \\
\hline Chocolatier 2 & $\mathrm{C} 2$ \\
\hline Coffee/Tea 1 & CT1 \\
\hline Coffee/Tea 2 & $\mathrm{CT} 2$ \\
\hline Deli 1 & D1 \\
\hline Deli 2 & D2 \\
\hline Distillery/Brewery 1 & DB1 \\
\hline Distillery/Brewery 2 & DB2 \\
\hline Distillery/Brewery 3 & DB3 \\
\hline Distillery/Brewery 4 & DB4 \\
\hline Accommodation 1 & EA1 \\
\hline Accommodation 4 & EA4 \\
\hline Accommodation 6 & EA6 \\
\hline Ice Cream 2 & IC 2 \\
\hline
\end{tabular}




\begin{tabular}{|l|l|} 
Drinks 1 & NAD1 \\
\hline Heidi White (Festival Director, EAT & Heidi \\
Cambridge) & \\
\hline Emma Thornton (CEO, Visit Cambridge and & Emma \\
Beyond) & \\
\hline
\end{tabular}

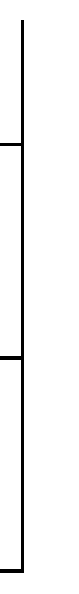

